\title{
Study on the Wetland's Scientific Attributes and Its Restoration in Baiyangdian Lake
}

\author{
Zhen Wang, Jisong Wu, Jingyang Xia* \\ School of Economics and Management \\ Beihang University \\ Beijing, China \\ xiajingyang@buaa.edu.cn
}

\begin{abstract}
Through an analysis of the wetland definition with legal effect, this paper gives an elaboration about a scientific conclusion that the scientific attribute of Baiyangdian Lake, Xiong'an is wetland rather than lake, and further defines the wetland's scientific attributes that are different from lake's. The scientific suggestions on wetland ecological restoration in Baiyangdian Lake are put forward. Finally, the specific measures in and suggestions on ecological governance in Baiyangdian are proposed.
\end{abstract}

Keywords-Baiyangdian Lake; Xiong'an new area; Wetland; Ecological restoration

\section{INTRODUCTION}

Located in center of the North China Plain, Baiyangdian Lake is the central zone of three counties, which make up Xiongan New Area, namely Rongcheng County, Anxin County, and Xiong County. As the largest inland freshwater lake wetland in the North China Plain, the Baiyangdian drainage area plays an important role in flood alleviation, water storage and sediment retention, water purification, climate regulation, replenishment of underground water in North China, drought mitigation, and maintenance of the ecosystems in Beijing, Tianjin and North China [1]. In recent years, the ecological environment of Baiyangdian has changed due to enormous changes of the hydrological environment in its basins, the fact that the amount of water into Baiyangdian tends to reduce significantly compared with the amount of that in previous years, and the influence of human activities. These changes have weakened its ecosystem services, and have severely limited the effects of wetland. In terms of ecological environment in "Planning Outlines of Xiong'an New Area, Hebei Province", it has been mentioned that an integrated plan should be made to improve the system of water, forest, farmlands, and lakes, and efforts should be made to protect the ecological environment in Baiyangdian so as to restore its function of what is called "the Lung of North China".

In recent years, wetland science has been the research focus worldwide. Wu Jisong led the deliberation and approval of the report about China's accession to the Convention on Wetlands, and took part in the signature process [2]. Wu put forward ecological engineering principles to be followed while advancing new types of urbanization in a large scale, by taking the hydraulic engineering in Guilin region as an example [3], and gave directions for Beilong wetland restoration in the Nenjiang River [4]. Jiang Chunbo, et al. took considerations into both the interaction between a wetland ecosystem and its surrounding ecosystem, and the response mechanism of the wetland ecosystem at the extreme environment conditions and improved the nature wetland ecological system assessment technology [5]. Liu Xiaoyan, et al. analyzed the changes of the wetland ecological features and did a lot of research on the realization of sustainable urban development with the ecological restoration project of Qingxi Wetland of Shanghai as the example [6]. Wu Xiaoqin set up methods for ecoenvironmental evaluation of the estuarine wetlands of Fujian Province in which the evaluation index system and assignment standard are included [7]. Chen Hong, et al. studied the changes of hydrological environment of Baiyangdian, and proposed to establish ecological water replenishment mechanism, comprehensively manage pollution sources, and set up a security system to promote integrated river basin management [8]. It could be seen that these studies focus on the evaluation of the ecosystem and the research of the evaluation index system. However, the research of the implementation of these evaluations, including specific restoration measures of the ecosystem and suggestions, is few; and the research on the wetland ecosystem restoration of Baiyangdian is fewer. This paper gives an analysis of the current ecological situation of the Baiyangdian wetland based on the comprehensive survey of and research on it, and put forward restoration suggestions and specific measures accordingly.

\section{WETLAND's SCIENTIFIC ATTRIBUTE OF BAIYANGDIAN}

\section{A. Definition of Wetland with Legal Effect}

The word "wetland" was not used in China before 1991. Instead, "lake" was often used, or, some more accurate wetlands were described as "swamp", "lakeshore", and "benchland". China officially accessed to the Ramsar Convention on Wetlands of International Importance especially as Waterfowl Habitat, known as the Convention on Wetlands, in 1992. It is understandable that there are different understandings outside the environmental field based on public daily experience, but it is mentionable that the definition of wetland is a scientific standard. Hence, its definition should follow the international interpretation. The definitions about wetland are summarized and listed in Table I. A wetland boasts three features: (1) More surface water, seasonal or perennial, fresh, brackish or salt, the depth of which is lower than 3 meters and changes every year. (2)Peat horizon or 
gleization of the subsoil, in which there is obvious gley horizon and peat horizon. (3) The wetland biota ecosystem with special water purification function.

TABLE I. DEFINITIONS OF WETLAND

\begin{tabular}{|c|c|c|c|}
\hline Source & Proposer & Time & Definition \\
\hline $\begin{array}{l}\text { Convention } \\
\text { Wetlands }\end{array}$ & Ramsar & 1971 & $\begin{array}{l}\text { "...wetlands are areas of marsh, fen, peatland or water, whether natural or artificial, } \\
\text { permanent or temporary, with water that is static or flowing, fresh, brackish or salt, } \\
\text { including areas of marine water the depth of which at low tide does not exceed six } \\
\text { meters."[9] }\end{array}$ \\
\hline Circular 39 & $\begin{array}{l}\text { The U.S. Fish and } \\
\text { Wide Service }\end{array}$ & $\begin{array}{l}1956, \\
1979\end{array}$ & $\begin{array}{l}\text { This Circular defined wetlands as "lands that are covered by shallow water, whether } \\
\text { temporary or permanent." In 1979, in order to adopt a classification of wetlands and } \\
\text { deepwater habitats, the UNFWS redefined wetlands as "lands transitional between } \\
\text { terrestrial and aquatic systems where the water table is usually at or near the surface or the } \\
\text { land is covered by shallow water..." }\end{array}$ \\
\hline Wetlands book & Mitsch \& Jamnes & 1986 & $\begin{array}{l}\text { In physical geography, a wetland is an environment "at the interface between truly } \\
\text { terrestrial ecosystems... and truly aquatic systems... making them different from each yet } \\
\text { highly dependent on both."[10] }\end{array}$ \\
\hline Webster Dictionary & $\begin{array}{l}\text { Merriam-Webster, } \\
\text { Inc. }\end{array}$ & 2000 & $\begin{array}{l}\text { Wetland is "land or areas that are covered often intermittently with shallow water or have } \\
\text { soil saturated with moisture." }\end{array}$ \\
\hline $\begin{array}{l}\text { Website of Wetlands in } \\
\text { Shangdong Province }\end{array}$ & $\begin{array}{l}\text { Shandong } \\
\text { Agricultural } \\
\text { University }\end{array}$ & 2004 & $\begin{array}{l}\text { Wetlands are lands transitional between terrestrial and aquatic systems, which are covered } \\
\text { by shallow surface water, or by ground-water which is generally closed to the surface [11]. }\end{array}$ \\
\hline $\begin{array}{lc}\text { Provisions } & \text { on } \\
\text { Administration } & \text { of } \\
\text { Wetland Protection } & \end{array}$ & $\begin{array}{l}\text { The State Forestry } \\
\text { Administration of } \\
\text { PRC }\end{array}$ & 2013 & $\begin{array}{l}\text { Wetland is "marine water the depth of which at low tide does not exceed six meters, } \\
\text { including swamp wetland, lacustrine wetland, riverine wetland, coastal wetland and other } \\
\text { natural wetlands, as well as habitats for special protected wildlife, native habitats for } \\
\text { special protected wild plants and other artificial wetlands. }\end{array}$ \\
\hline $\begin{array}{l}\text { Water Conservancy } \\
\text { Dictionary }\end{array}$ & Hohai University & 2015 & $\begin{array}{l}\text { "Wetland: shallow water, whether natural or artificial, with water that is static or flowing, } \\
\text { and offshore waters the depth of which at low tide does not exceed six meters." }\end{array}$ \\
\hline
\end{tabular}

\section{B. Baiyangdian Cannot be Classified as a Lake}

Lakes are classified into 9 types according to their origin, including tectonic lakes, volcanic lakes, glacial lakes, landslide lakes, solution lakes, fluvial lakes, aeolian lakes, shoreline lakes, anthropomorphic lakes other types of lakes. However, Baiyangdian cannot be classified as any types of lakes mentioned above. There is only similarity of the origin between Baiyangdian and fluvial lakes. We could see the definition of wetland in Provisions on Administration of Wetland Protection by the state forestry administration of the PRC in Table I. Its wetland classification is worth discussing: "lacustrine wetland" should be classified as "coastal lacustrine wetland", and its scientific attribute is still home to "wetland"; "riverine wetland" should be defined as "river flats", and its scientific attribute is also "wetland". However, it is noticeable that Baiyangdian`s main part consists of riverine wetland and swamp wetland.

On June 26, 2003, an article by Wu Jisong, titled "A Proposal of Setting up a New Disciplinary of Resources Systems Engineering Management" (the resource management of circular economy), was published on "the Education Week" of Guangming Daily. Wu established a synergetic oriented study of the ecological restoration and economic development of Baiyangdian in Xiong'an New Area. Due to Wu's work, subsequently, an International Wetland Forum was held. Major wetland experts attended this forum, and they reached consensus that the scientific attribute of Baiyangdian is wetland rather than lake.

It is stated in the major engineering program lists of the 13th Five-Year Plan of National Wetland Protection that "Baiyangdian is the largest inland freshwater lake wetland", and it has been listed in the wetland restoration projects of the provincial natural reserve of Heibei province. Also, Baiyangdian was defined as wetland in the General Plan of Ecological Environment Protection of Baiyangdian (20102015) approved by the Baoding City Government. In 2015, Baiyangdian and other 12 wetlands were listed in the first batch of provincial important wetlands list of Hebei Province. In 2018, China's State Council approved the Planning Outlines of Xiong'an New Area, Hebei Province, and affirmed the scientific conclusion that Baiyangdian is classified as wetland. Especially, the plan that "wetland ecology will be integrated in urban space" in the approval manifests the importance of the study of this scientific conclusion to the plan and development of Xiong'an New Area.

\section{Scientific Attributes of Wetland Differring from Lake}

1) Geological attribute: A wetland boasts peat horizon at the bottom, or obvious woody or herbaceous gley horizon in its soil, both of which are its unique geological attributes and major criteria, while lakes do not have these features. Wetlands are classified into 6 types, including herb peat horizon, woodherb peat horizon, moss peat horizon, wood-herb-moss peat horizon, wood gley horizon and herb-wood gley horizon, according to wetland's vegetation feature. Baiyangdian has herb-wood gley horizon in its soil, so it can be classified as this type of wetland. The major helophytes in the Baiyangdian are phragmites communis, lotus, water chestnut, lotus root, which all belongs to the vegetation type of herb-wood gley horizon. Baiyangdian is classified as alluvial plain marsh, which is dominated by marsh. The forming process of bog soil actually 
consists of two aspects, namely the process of the paludification of surface soil and the gleization of subsoil. Geological studies show that in the middle period of Holocene, black clay/peat was developing in Baiyangdian. Peat, also known as turf, is the lowest rank of coal. The Huabei Oilfield, located in Renqiu, south of Baiyangdian Lake, provides the evidence. The fact that Daqing Oilfield used to be a wetland also proves that Baiyangdian has this geological attribute.

\section{2) Hydrological Attribute}

a) The depth of a wetland usually does not exceed 3 meters with the amplitude of 15\%: It is wetland's unique hydrological feature. The average depth of Baiyangdian for several years is 2.92 meters. The water level of Baiyangdian depends on its water storage capacity, while its water level gradually increases from the Lake's edge to its center. Hence, its average depth is no more than 3 metere. In addition, its average depth in dry season is no more than 2 meters except the several dryout in its history. Baiyangdian boasts more than 3700 channels, which is unusual to wetlands in the world. The depth of some area is more than 3 meters, but it is not general for Baiyangdian; rather, it is a special type of ecological wetland. The reed field, the vegetable garden and other lands accounts for $46.95 \%$ of the whole Baiyangdian area, and the water area makes up 53.05\%. The channel area and shallow water area accounts for $7.4 \%$ and about $41.1 \%$ of the water area respectively. As these channels, at the lee, are characterized by small areas of water surface, receiving more sunlight, and the water temperature's rising up quickly, the aquatic flora and fauna and birds in the wetland are provided sound living conditions. In addition, the shallow water offers sunlight condition, which allows special helophytes to live in the wetland.

b) Compared with the water level of a lake, the water level of a wetland is unstable, and has obvious interannual variations: Baiyangdian shares these features. The demand of stable water level to a wetland means transforming it into a lake, which is unscientific. In general, the water level amplitude of a wetland is from $10 \%$ to $30 \%$. Only in this way, the helophytes could receive sunlight and grow up, and some special plants with the function of water purification can work. Similarly, the water level of Baiyangdian has obvious interannual variations, with the minimum of $100 \mathrm{~km}^{2}$ and the maximum of $360 \mathrm{~km}^{2}$. According to the historical record, Baiyangdian dried out several times, among which the longest period was from 1983 to 1988 . However, the Lake could still recover from it.

3) Ecological attribute: It is the ecological feature of a wetland that there is a special ecosystem for flora and fauna. In Baiyangdiane, there is an ecosystem for special helophytes including phragmites australis, water chestnut, Euryale ferox and other special spices, and for special animals including mandarin fish, eels and other special fishes and transit waterfowls. This forms an obvious ecological feature of a wetland. Baiyangdian is the habitat for bustard and other rare water birds. Some water birds also choose lakes as their habitats, but there are a few in number and a few in pieces and they just stay for a short time. In Baiyangdian Lake, helophytes are remarkable, in which phragmites australis, as dominant communities, covers an extensive area, while the areas of Euryale ferox, water chestnut, lotus and other spices decrease dramatically. For instance, in the early 1990s, the average areas of Euryale ferox and water chestnut were 133.3 ha. and 142.8 ha., respectively. However, the current communities of them are located in Dawang village and Xiaoyang Lake, and belong to artificial communities. Baiyangdian, as a lying-low wetland, is an ideal place for phragmites australis. Phragmites australis is distributed at the water's edge and at the platform. As this kind of helophyte is inclusive to water depth, it can form a community, be it wet soil or perennial water-logged soil, and the depth of a few centimetres or that of more than 1 meter.

4) Biochemical attribute: Wetlands boast greater water purification than lakes, so they are known as "lungs of the earth". Currently, the average water quality of Baiyangdian has reached Type V, and becomes "sick in lung". A large area of phragmites australis covered in Baiyangdian works well in water purification, and its purification effects tends to be apparently different from different seasons. When the helophytes are in their utmost luxuriance, the purification function works well. Hence, before 2020, it should be promised that the water quality is no lower than Water Type III in the $2 / 3$ of each year, and no lower than Water Type VI for the rest time of each year. This is what lakes are not equipped with.

\section{SUGGESTIONS ON ECOLOGICAL RESTORATION OF BAIYANGDIAN LAKE}

\section{A. Reasonably Planning Ecological Water Requirements}

1) Before 2003, water requirements of Baiyangdian were never calculated according to the water level changes: In Baiyangdian, the rigid water requirements are 200 million $\mathrm{m}^{3}$ (supplementing the evaporation). However, the wetland features mentioned before demonstrates its changeable water level, so it is unreasonable to have this water level demand. As the average gap between the input and output water amount from 2006 to 2015 is 128 million $\mathrm{m}^{3}$, only 120 to 200 million $\mathrm{m}^{3}$ water are needed in the first to third year of restoration. In addition, supplementary water could be reduced and could be increased scientifically at the dry season lasting more than 2 years. This could save a large amount of water and maintain the agricultural production in Hebei province.

2) While taking Wangkuai Reservoir and Xi Dayang Reservoir as supplementary water sources, we should learn how much water can be transferred into Baiyangdian without taking into consideration of the influence of dry years and wet years. The calculation must be accurate so as to guarantee water sources.

3) The rate of the reclaimed water utilization should be improved: It is in accordance with the principles of the recycle of water resources and pursuing harmony with nature 
to use reclaimed water as much as possible. Currently, the reclaimed water utilization in Beijing has reached 1 billion $\mathrm{m}^{3}$, accounting for $25 \%$ of the overall water supply. The reclaimed water utilization in Xiong'an New Area should be no lower than this proportion.

4) The water conservation standards in Baiyangdian should be made according to the international standards: The domestic water use and the industrial water use should be no higher than the current amount in Beijing and Tianjin. Practice and experience demonstrate that water saving is the most significant factor for water governance. According to the plan, the population in this region will be 2.5 million by 2030 . Per capita annual water demand in Beijing is $128.5 \mathrm{~m}^{3}$, while in Paris Region is just $80 \mathrm{~m}^{3}$ (due to its large amount of rain). Per capita annual water demand here should be no more than that in Beijing. The industrial water use index and ten thousand yuan GDP water use index should be made. Besides, tools of domestic water conservation in urban areas should be equipped, the specific measures of industrial circulating water and agricultural water conservation and irrigation should be taken.

\section{B. Crucial Points of Wetland Ecological Restoration}

1) Wetland Ecological Restoration is an ecosystem restoration including flora and fauna: The ecological restoration should follow the principle of giving priority to the restoration of local spices, rather than just changing the water or desilting. Wetlands, as "the lungs of the earth", mainly function as water purification. The restoration of water function is mainly to restore the helophyte systems, as the expansion of phragmites australis area, the regeneration of water chestnut and Euryale ferox, etc. The area of phragmites australis should be increased from 5633 ha. to 7000 ha., reaching 8000 ha which was the area before Liberation. There used to be more than 10,000 trees in Baiyangdian, but they were all cut down for the use of flood control. Hence, the local trees should be replanted properly to restore the wetland forest belt system of Arbor.

2) Ground-water is the most important and sustainable water source in wetland ecosystem: The most important thing of wetland restoration is to maintain ground-water depth, mainly relying on the surface water to replenish water. Currently, the ground-water in Xiong'an New Area has been overexploited. Hence, the ground-water cannot be the main water supply. The ecological water should be kept to form the sustainable basic gley horizon in the wetland and to protect and develop the ecosystem of Baiyangdian. Concrete measures should be taken in gradually restoring the depth of ground-water within 5 meters.

3) It should be prudent while resilting in case of destroying the gley horizon, for it is one of the major structures of wetland ecosystem, and the foundation of water purification: Also, the chemical reactions of a wetland mostly take place in the gley horizon, and the production of chemical substances is critical to the growth of helophytes.

\section{Principles of Balancing Wetland Ecological Space}

1) Ecological buffer zones cannot be too large, or more water would be used.

2) A sound environment for people`s living and work should be created with Chinese Characteristics: When it comes to the issue of relocation, concrete calculations should follow the international standards. The principles are as follows: (1) Instead of relocating the phragmites australisthe fields, the area of phragmites australis should be expanded. The related farmer population should be increase by at least 15\%. (2) Those polluting aquacultures should be relocated, while people who turn to the culture-oriented tourism do not have to move out.

3) Baiyangdian itself is an area for flood discharge and sheet flood. Hence, suggestions on embankment should be reasonable: According to our research, it is feasible to build a dyke with a length of $30 \mathrm{~km}$ along the right dyke of South Juma River and its Baigou diversion canal, the north dyke of Xing'an River, and the left dyke of Ping River, so as to cope with once-in-a-century flood. The preservation zone plays an important role in flood alleviation, water conservation, climate regulation, and the maintenance of biodiversity. Flood control could be combined with the northern flood storage and detention area, and the buffer zone of the preservation zone and the experimental tour area could be combined with flood storage and detention area. Moreover, the appropriate width of these zones and areas, and auxiliary materials should be also take into scientific consideration. These zones and areas could be used as golf course, natural grass field and park in daily life, and are closed to the public when it comes to flood. Rain and flood irrigation can also be carried out so as to form a self-sustainable protection zone with the combination of utilization and preservation.

\section{ECOlOGICAL GOVERnANCE MEASURES OF BAIYANGDIAN}

(1) Setting up Sewage Treatment Plant in a Scientific and Reasonable Way. The average water quality in Baiyangdian has reached Type $\mathrm{V}$, so it is a matter of urgency to improve the rate of sewage treatment. Sewage treatment mainly relies on sewage treatment plants, and it demands scientific basis to set up one. Firstly, the building should be organized based on the theory of hydrodynamics and water function zones, as well as according to the statistics; secondly, sewage treatment should be improved by adjusting measures to local conditions, by different methods, and in different levels. It is notable that topography needs to be taken into full consideration while using physical methods, metals should be paid much attention when using chemical methods, and that biological methods should be combined with wetland features. By doing like this, we could gradually restore Baiyangdian to "the lung of North China".

(2) Improving the Water Regulation. By connecting all channels, a unified water system could be established so as to improve the network management combined with water 
function zones in the watershed and to implement real-time monitoring.

(3) Making Risk Prediction and Management in Case of Pollution Incidents. The flood period should be paid special attention, for the most background pollutions of rivers might flow into the Lake at that period, which is the biggest pollution incident. The existing sewage interception measures cannot guarantee the water quality at that period. Hence, much work should be done to make improvement.

(4) Strengthening Systemic Thinking. The platform, water, forest, field, the Lake and the city are arranged uniformly. Suppliers are surface water, ground-water and other available water, and demanders are domestic water, industrial water, and ecological water. The synergy and supply-side structural reform of the six factors mentioned above should be taken into consideration. Through the analysis by non-equilibrium complex giant system, a dynamic balance of supply and demand would be achieved so as to realize systematic governance. Fig. 1 shows the supply-demand balance of water resource in Baiyangdian.

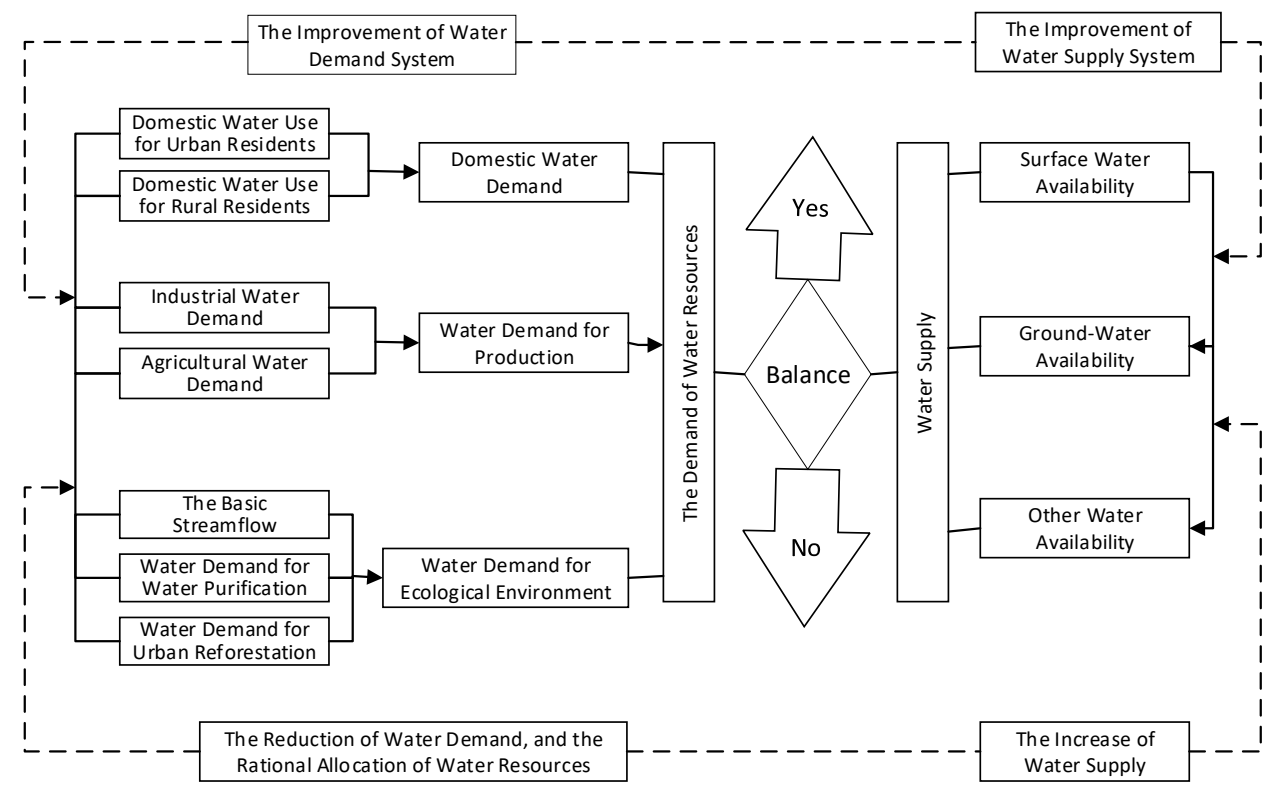

Fig. 1. Supply-demand balance of water resource in Baiyangdian.

(5) In the plan, it is essential to borrow the experience from the ecological governance and protection in Zhalong Wetland. Also, it is necessary to learn lessons from the lakebed governance of Old Summer Palace in Beijing, and the multiple governance efforts in Dianchi Lake of Yunnan Province due to the lack of analysis from a large scale system. A blueprint should be outlined and efforts must be made to remain committed to it.

\section{V.CONCLUSIONS}

In this paper, we analyze the definition of wetland with legal effect and further elaborate the scientific conclusion that "the scientific attribute of Baiyangdian is wetland rather than lake". Also, we define the scientific attributes of wetland which differs from lake. We put forward scientific suggestions on the wetland ecological restoration in Baiyangdian Lake: (1) Making a reasonable plan for ecological water requirements of Baiyangdian; (2) Improving the restoration measures of the wetland ecosystem; (3) Balancing the wetland ecological space. Finally, we propose the ecological governance measures for Baiyangdian, mainly from the perspective of the plan of setting up sewage treatment plant, water monitoring, the response to pollution incidents, the balance of water supply and demand in Baiyangdian and successful experience absorbed from other projects. This also offers an important reference to the implementation of Planning Outlines of Xiong'an New Area, Hebei Province.

\section{REFERENCES}

[1] Y.H. Li, B.S. Cui, and Z.F. Yang, "Influence of Hydrological Characteristic Change of Baiyangdian on the Ecological Environment in Wetland," Journal of Natural Resources, vol. 19(1), pp. 62-68, 2004.

[2] J.S. Wu, "Introduction to Modern Water Resource Management," Beijing: China WaterPower Press, 2002.

[3] J.S. Wu, "New Urbanization Based on the Engineering Management of the Ecological Civilization," Engineering Science, vol. 15(11), pp. 19$23,2013$.

[4] J.S. Wu, "River Governance Expert Talks about River Chief," Beijing: Beihang University Press, 2017.

[5] C.B. Jiang, E.Q. Hui, and Q.R. Kong, "Advances in Assessment Research of Nature Wetland," Ecological Environment, Vol. 16(4), pp. 1304-1307, 2007.

[6] X.Y. Liu and Y.L. Li, "Research on Wetland Ecological Restoration and Landscape Planning-With the Ecological Restoration Project of Qingxi Wetland of Shanghai as the Example," Chinese Landscape Architecture, vol. 3(11), pp. 75-78, 2000.

[7] X.Q. Wu, Ecological Environmental Evaluation of the Estuarine Wetland of Fujian Provincc-Take the Estuarine Wetland of Jiulong River as an Example, Fujian: Fujian Normal University, 2005.

[8] H. Chen and J.Z. Cao, "The Research on the Reality of Baiyangdian Wetland and its Restoration Measures," Management \& Technology of SME, vol. 2016(11), pp. 109-110, 2016. 
[9] Office of International Standards and Legal AF-FAIRS, UNESCO, Convention on Wetlands of International Importance Especially as Waterfowl Habitat [EB/OL], http://www.ramsar.org/key conv e.htm, 2004-05-08.

[10] W.J. Mitsch and G.G. Jamnes, "Wetlands", New York: Van No strand Reinhold, 1986
[11] International Programs of Shandong Agricultural University, Wetland Definition [EB/OL], http://sdwl. sdau.edu.cn/rssd.htm, 2004-05-08.

[12] Microsoft Corporation, Encarta [EB/OL], http://encarta.msn.com, 200405-08. 